\title{
Peningkatan Keterampilan Menulis Teks Cerita Pendek dengan Menggunakan Adobe Flash (Improving Short Story Text Writing Skills Using Adobe Flash)
}

\section{Wikanengsih $^{\mathrm{a}, 1}$ dan Puspita Ningrum ${ }^{\mathrm{b}, 2}$}

${ }^{a}$ IKIP Siliwangi, Cimahi, Indonesia

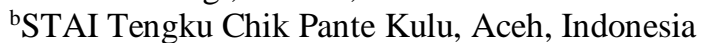

1wikanengsih@ikipsiliwangi.ac.id; ${ }^{2}$ puspita@gmail.com

\begin{tabular}{ll}
\hline Article info & A B S T R A C T \\
\hline Article history: & This study aims to describe the improvement of students' skills in \\
Revised : 09-01-2021 & writing short story texts. This quasi-experimental study used \\
Accepted:18-05-2021 & pretest-posttest in the control and experimental groups. The \\
& population in this study were students of class VII SMK with a \\
& purposive sample of 46 people. The research was conducted in \\
& the period from January 20 to February 5, 2020. The instruments \\
& used were in the form of tests and non-tests, validated by two \\
& experts. Based on the results and discussion, it is concluded that \\
& the discovery learning method assisted by Adobe Flash can \\
& improve the ability to write short stories and can increase \\
& learning motivation. Students become challenged in solving the \\
& problems given by the teacher.
\end{tabular}

Keywords:

writing short stories motivation to learn discovery learning adobe flash

Penelitian ini bertujuan untuk mendeskripsikan peningkatan keterampilan siswa dalam menulis teks cerita pendek. Penelitian eksperimen kuasi ini menggunakan pretes-postes pada kelompok kontrol dan eksperimen. Populasi dalam penelitian ini adalah siswa SMK kelas VII dengan sampel purposive sebanyak 46 orang. Penelitian dilakukan pada rentang waktu 20 Januari - 5 Februari 2020. Instrumen yang digunakan berupa tes dan non tes dengan divalidasi oleh dua orang ahli. Berdasarkan hasil dan pembahasan diperoleh simpulan bahwa metode discovery learning berbantuan adobe flash dapat meningkatkan kemampuan menulis cerita pendek dan dapat meningkatkan motivasi belajar. Siswa menjadi tertantang dalam menyelesaikan soal-soal yang diberikan guru.

Copyright @ 2021 Institut Agama Islam Negeri Syekh Nurjati Cirebon. All rights reserved.

\section{PENDAHULUAN}

Empat kemampuan penting yang harus dikuasai pada era 4.0 adalah kemampuan berpikir kritis, berpikir kreatif, kolaboratif dan komunikasi. Komunikasi dapat dilakukan melalui lisan dan tulis. Oleh karena itu, siswa diharapkan memiliki kemampuan menulis berbagai jenis teks sehingga dalam kurikulum yang berlaku saat ini terdapat kompetensi dasar yang harus dikuasai siswa, diantaranya kompetensi menulis teks cerita pendek. Cerita pendek merupakan penyampaian ide atau gagasan, pengalaman, melalui media bahasa tulis yang disusun sebaik mungkin, sehingga membentuk cerita ke dalam fiksi serta dapat selesai dibaca kira-kira 10 sampai 30 menit (Hidayati, 2009). Menulis teks cerita pendek dapat dijadikan sebagai kegiatan untuk melatih berpikir kreatif karena melalui menulis cerita pendek siswa dapat menuangkan imajinasi yang mereka miliki (Saputro, 2017). 
Fakta di lapangan, kemampuan siswa dalam menyusun cerita pendek masih rendah. Hal ini berdasarkan hasil wawancara dengan guru Bahasa Indonesia yang mengajar di SMK yang mengungkapkan bahwa siswa kurang memiliki motivasi dalam menulis cerita pendek sehingga hasil tulisan siswa dalam bentuk cerita pendek masih rendah. Dewi, Martha, \& Wendra (2016) melaporkan bahwa terdapat beberapa faktor yang menyebabkan kemampuan siswa dalam menulis rendah, diantaranya kurangnya pengetahuan siswa tentang teknik menulis, proses belajar mengajar di kelas yang cenderung membosankan bagi siswa, pendekatan pembelajaran yang kurang tepat yang digunakan oleh guru, bahkan media pembelajaran yang kurang bervariasi. Demikian juga penelitian yang dilaporkan Agustina et al. (2015), Musyafa (2020), dan Nasution et al. (2020) bahwa siswa mengalami kesulitan menuangkan ide ke dalam cerita pendek, penggunaan ejaan dan keruntutan cerita dan motivasi menulis cerita pendek kurang.

Faktor utama penyebab siswa kesulitan dalam menulis diantaranya, siswa tidak termotivasi karena selalu diberi tugas oleh guru padahal motivasi sangat diperlukan untuk mencapai sebuah tujuan (Wulandari et al., 2012). Motivasi belajar merupakan dorongan yang berasal dari dalam dan dari luar diri seseorang yang sedang mengikuti pembelajaran untuk mengubah perilaku dengan beberapa indikator dan unsur yang mendukung (Thobroni, Muhammad \& Mustofa, 2011; Uno, 2014). Hal ini akan sangat berpengaruh pada kualitas siswa dalam belajar menulis karena kalau siswa tidak memiliki motivasi maka kualitas tulisan pun rendah. Adapun indikator motivasi dikemukakan oleh beberapa ahli, diantaranya menurut, yaitu 1) ada hasrat untuk berhasil; 2) adanya semangat dan keperluan yang tinggi ketika belajar; 3) timbulnya harapan atau keinginan masa yang akan datang; 4) adanya penghargaan pada saat belajar; 5) munculnya hal menarik pada saat belajar; dan 6) adanya keadaan sekitar yang kondusif yang dapat meningkatkan siswa dapat belajar dengan cara yang menyenangkan (Uno, 2014). Adapun indikator motivasi lainnya mencakup: 1) tekun menghadapi tugas yang diberikan; 2) ulet dalam menghadapi kesulitan; 3) menunjukkan minat terhadap hal-hal yang di luar kebiasaan; 4) lebih suka bekerja secara mandiri; 5) cepat bosan pada kegiatan yang bersifat rutin dan mekanis; 6) mempertahankan pendapat; 7) tidak mudah menyerah pada keyakinan; dan 8) senang mencari dan memecahkan masalah (Sardiman, 2003).

Sebagai usaha dalam meningkatkan kemampuan menulis cerita pendek dan meningkatkan motivasi siswa diperlukan penggunaan sebuah metode pembelajaran yang dapat meningkatkan kemampuan dan motivasi siswa dalam menulis cerita pendek. Beberapa penelitian terdahulu tentang upaya peningkatan kemampuan menulis teks cerita pendek dengan menggunakan berbagai metode telah dilakukan oleh Boko \& Saleh, (2020), Kusnida et al., (2015), Hudhana \& Sulaeman, (2019), Pradita, (2020), Listini \& Saraswati, (2017), Agustina et al., (2015), Sarudi, (2018), dan Kurnianingtyas, (2015). Hasil penelitian-penelitian tersebut melaporkan bahwa metode yang digunakan oleh masing-masing peneliti dapat meningkatkan kemampuan siswa dalam menulis cerita pendek. Belum ditemukan hasil penelitian terdahulu yang melaporkan tentang penggunaan sebuah metode pembelajaran untuk meningkatkan kemampuan menulis cerita pendek beserta motivasi belajarnya. Oleh karena itu, penelitian ini mencoba menggunakan discovery learning berbantuan adobe flash.

Discovery learning merupakan proses belajar yang dapat menciptakan keadaan dan suasana belajar yang berkaitan dengan permasalahan, mendorong 
siswa dengan pertanyaan yang beragam, mendorong siswa dapat memecahkan pertanyaan, dan dapat melakukan uji coba. Belajar dengan menggunakan discovery learning harapannya dapat meningkatkan daya nalar dan meningkatkan kemampuan untuk dapat berpikir dengan cara bebas dan melatih keterampilan kognitif siswa dengan cara menemukan dan memecahkan permasalahan yang ditemui dengan pengetahuan yang sudah dimiliki sebelumnya dan menghasilkan pengetahuan yang benar-benar bermakna bagi dirinya (Chusni \& Edy, 2014). Discovery learning menekankan pada pelibatan seluruh kompetensi siswa sehingga siswa bertindak lebih aktif dalam memecahkan masalah (Lidiana et al., 2018). Discovery learning merupakan proses mental yang berarti siswa mampu mengasimilasikan suatu konsep atau prinsip. Proses mental itu berupa mengamati, mencerna, mengerti, menggolongkan, membuat praduga, menjelaskan mengukur, menyusun kesimpulan dan sebagainya (Mutmainna \& Jafar, 2015). Dengan menerapkan metode discovery learning ini, diharapkan dapat meningkatkan kemampuan menulis dan motivasi belajar siswa dalam belajar menulis cerita pendek.

Hal baru yang merupakan urgensi penelitian ini yaitu penggunaan adobe flash pada metode discovery learning. Adobe flash adalah sebuah aplikasi yang dapat digunakan pada metode pembelajaran. Adobe flash cs4 merupakan suatu program animasi yang dapat dipergunakan untuk pembuatan animasi 2d. Adobe flash cs4 merupakan seri yang ke 10, sebelumnya flash masih dimiliki oleh macromedia tapi setelah seri yang ke 9 dan ke 10 sudah dimiliki oleh adobe. Fungsi flash dari adobe dan flash dari macromedia itu sama, perbedaannya hanya terletak dari action script dan fitur-fiturnya. Fungsi dari flash itu sendiri yaitu untuk membuat animasi $2 \mathrm{~d}$ seperti pembuatan multimedia pembelajaran, move clip, banner animasi dan lainlain. Flash sangat menguntungkan untuk dunia kerja dan media yang menarik untuk pembelajaran di kelas karena sifatnya yang menarik dan inovatif.

Beberapa penelitian yang menggunakan adobe flash dan telah membuktikan keefektifannya diantaranya dilaporkan oleh oleh Muyaroah \& Fajartia (2017) pada pembelajaran biologi. Demikian juga Maulidta \& Sukartiningsih (2018) pada pembelajaran menulis teks eksposisi serta Rahmaibu, Ahmadi, \& Prasetyaningsih (2016) pada pendidikan kewarganegaraan. Belum ditemukan penelitian tentang menulis cerita pendek yang menggunakan discovery learning berbantuan adobe flash. Kelebihan dari adobe flash dalam pembelajaran menulis cerita pendek, yaitu pada saat memberi pemahaman tentang teori cerita pendek. Oleh karena itu, kompetensi siswa dan motivasinya diharapkan dapat meningkat setelah metode discovery learning diterapkan.

Berdasarkan latar belakang di atas, peneliti melakukan penelitian dengan menerapkan metode discovery learning berbantuan media adobe flash dengan tujuan untuk: 1) mengetahui peningkatan kemampuan siswa dalam menulis cerita pendek setelah menerima pembelajaran dengan menggunakan metode discovery learning berbantuan adobe flash; 2) mengetahui peningkatan motivasi belajar siswa yang pembelajarannya menggunakan metode discovery learning berbantuan media interaktif adobe flash; 3) mengetahui hubungan antara motivasi belajar dengan kemampuan menulis teks cerita pendek siswa; 4) mengetahui kesulitan siswa pada saat menyelesaikan soal-soal pengetahuan menulis teks cerita pendek dan menyelesaikan tugas praktik menulis teks cerita pendek.

\section{METODE}


Penelitian ini menggunakan pendekatan penelitian kuantitatif dengan jenis penelitian eksperimen kuasi. Populasi yang diambil dalam penelitian ini adalah siswa kelas XI Semester II SMK Komputer Arya Karina Pratama Cianjur tahun pelajaran 2019/2020. Sampel ditentukan dengan cara acak kelas dengan memilih dua kelas dari empat kelas yang ada. Justifikasi kelas yang dipilih berdasarkan hasil penilaian guru Bahasa Indonesia yang mengajar di sekolah tempat penelitian dilakukan. Kelas XI OTKP 3 dijadikan sebagai kelas eksperimen dan kelas XI OTKP 2 dijadikan kelas kontrol. Masing-masing kelompok mendapat perlakuan yang berbeda. Kelas eksperimen menggunakan metode pembelajaran discovery learning berbantuan media interaktif adobe flash, sedangkan pada kelompok kontrol menggunakan metode konvensional. Waktu pelaksanaan penelitian tampak pada tabel di bawah ini.

Tabel 1. Waktu Pelaksanaan Penelitian

\begin{tabular}{ccc}
\hline No & Kelas & Tanggal Pelaksanaan \\
\hline 1. & XI OTKP 3 (eksperimen) & 20 Januari 2020 \\
& & 27 Januari 2020 \\
& & 10 Februari 2020 \\
2. & XI OTKP 2(kontrol) & 22 Januari 2020 \\
& & 29 Januari 2020 \\
& 5 Februari 2020 \\
\hline
\end{tabular}

Desain penelitian yang dipergunakan seperti tampak pada gambar di bawah ini.

$$
\begin{array}{cccc}
E & O_{1} & x & O_{2} \\
K & O_{1} & & O_{2}
\end{array}
$$

\section{Gambar 1. Desain Penelitian}

Keterangan :

(Sugiyono, 2010)

$$
\begin{aligned}
& \mathrm{E} \quad \text { : Kelas Eksperimen } \\
& \mathrm{K} \quad \text { : Kelas Kontrol } \\
& \mathrm{O} 1 \quad \text { : Uji awal pada kelompok eksperimen } \\
& \mathrm{O} 2 \quad \text { : Uji akhir pada kelompok eksperimen } \\
& \mathrm{X} \quad \text { :Perlakuan pada kelompok eksperimen } \\
& \text { cerita pendek dengan menggunakan metode } d \\
& \text { interaktif adobe flash } \\
& \mathrm{O} 3 \quad \text { : Uji awal pada kelompok kontrol } \\
& \mathrm{O} 4 \quad \text { : Uji akhir pada kelompok kontrol }
\end{aligned}
$$

$\mathrm{X} \quad$ :Perlakuan pada kelompok eksperimen berupa pembelajaran menulis teks cerita pendek dengan menggunakan metode discovery learning berbantuan media

Pengambilan data pada penelitian ini dilakukan melalui penggunaan dua buah instrumen penelitian, yaitu, tes dan non tes. Instrumen tes berupa soal-soal yang digunakan untuk mengukur pengetahuan tentang teori menulis teks cerpen dan soal praktik untuk mengukur keterampilan menulisnya. Indikator soal berkaitan dengan unsur pembangun cerita pendek. Instrumen tes dikembangkan berdasarkan indikator yang mengacu pada teori cerita pendek dan divalidasi oleh dua orang ahli agar memiliki validitas isi, kemudian diujicobakan untuk mengetahui validitas empiris, reliabilitas, daya pembeda dan indeks kesukaran. Instrumen non tes berupa skala sikap Likert digunakan untuk mengukur motivasi siswa yang terdiri dari pernyataan positif dan negatif sesuai dengan indikator motivasi dari teori yang 
dikaji. Prosedur penelitian dilakukan melalui tahap persiapan, pelaksanaan yang mencakup tes awal dan perlakuan penggunaan metode dan tahap evaluasi melalui tes akhir untuk mengetahui pengaruh. Pengolahan data dilakukan dengan menggunakan bantuan software SPSS versi 15.0 for windows.

\section{HASIL DAN PEMBAHASAN}

Temuan tentang kemampuan menulis cerita pendek dan motivasi belajar siswa disajikan pada tabel 1 . Setelah diuji normalitas sebaran data kemampuan menulis cerita pendek diperoleh bahwa data berdistribusi normal sehingga dilakukan perhitungan melalui uji $t$.

Tabel 2.

Rekapitulasi Hasil Kemampuan Menulis Teks Cerita Pendek (KMTCP) dan Motivasi Belajar (MB)

\begin{tabular}{|c|c|c|c|c|c|c|c|c|c|c|}
\hline \multirow[t]{2}{*}{ No } & \multirow[t]{2}{*}{$\begin{array}{c}\text { Jenis } \\
\text { Kemampuan }\end{array}$} & \multirow[t]{2}{*}{$\mathrm{n}$} & \multirow[t]{2}{*}{$\begin{array}{l}\text { Skor } \\
\text { Ideal }\end{array}$} & \multirow[t]{2}{*}{$\begin{array}{c}\text { Data } \\
\text { Statistik }\end{array}$} & \multicolumn{3}{|c|}{$\begin{array}{c}\text { Discovery learning } \\
\text { Berbantuan Adobe Flash } \\
\text { (DLBAF) }\end{array}$} & \multicolumn{3}{|c|}{ Konvensional } \\
\hline & & & & & Pretest & Postest & $\mathrm{N}$-gain & Pretest & Postest & $\mathrm{N}$-gain \\
\hline 1. & KMTCP & 23 & 100 & & 54,44 & 85,22 & 66,41 & 52.15 & 72,80 & 41,48 \\
\hline 2. & MB & 23 & 120 & $\begin{array}{l}\% \\
\text { SD } \\
\% \\
\text { SD }\end{array}$ & $\begin{array}{l}54,44 \% \\
7,66 \\
80,3 \\
66,91 \%\end{array}$ & $\begin{array}{l}85,22 \% \\
5,56 \\
117 \\
97,50 \%\end{array}$ & 77,6 & $\begin{array}{l}52,15 \% \\
7,54 \\
61,06 \\
50,88\end{array}$ & $\begin{array}{l}72,80 \% \\
4,90 \\
92,87 \\
77,39\end{array}$ & 68.6 \\
\hline
\end{tabular}

Tabel 3.

\begin{tabular}{lllllll}
\multicolumn{8}{c}{ Hasil Uji Hipotesis Kemampuan Menulis Cerita Pendek dan Motivasi } \\
Belajar
\end{tabular}

Konvensional 92,87. 9,512 23

Catatan: skor ideal KMCP: 100; skor ideal MB: 120

Berdasarkan data pada tabel 2 dan hasil pengujian hipotesis pada tabel 3 penelitian ini menghasilkan beberapa temuan sebagai berikut. a) Kemampuan menulis teks cerita pendek siswa di kelas yang menerima pembelajaran dengan menggunakan metode DLBAF tergolong pada kategori sangat baik $(85,22 \%$ dari skor ideal ), kemampuan ini lebih baik daripada kemampuan siswa pada kelas yang 
menggunakan metode pembelajaran konvensional yang tergolong baik $(72,80 \%$ dari skor ideal). Temuan pada penelitian ini serupa dengan beberapa temuan lain di antaranya penelitian Darari (2017) pada pelajaran Matematika dan Rahmaibu, Ahmadi, \& Prasetyaningsih (2016) pada pembelajaran Pendidikan Kewarganegaraan. Selain dapat, meningkatkan kemampuan kognitif siswa, penggunaan Adobe flash juga dapat meningkatkan aktivitas siswa.

Demikian juga menurut hasil penelitian yang dilaporkan Lailiya (2015). Peningkatan aktivitas siswa ini berdasarkan pengamatan penulis karena Adobe Flash memberikan tantangan baru bagi siswa pada saat mengerjakan tugas-tugas yang diberikan guru sehingga para siswa memiliki pengalaman baru dalam belajar. Pengalaman belajar inilah yang seharusnya disiapkan guru pada saat memilih metode pembelajaran. Peran guru yang sesungguhnya adalah pemberi kesempatan kepada siswa untuk memiliki pengalaman belajar (Sanjaya, 2012). Pengalaman belajar yang diperoleh siswa pada saat pembelajaran dapat menjadi pengalaman bermakna yang bermanfaat bagi dirinya; b) Terdapat perbedaan motivasi belajar siswa di kelas yang menerima pembelajaran dengan menggunakan metode DLBAF dengan siswa di kelas yang menerima metode pembelajaran konvensional.

Motivasi belajar siswa di kelas eksperimen lebih baik dari motivasi siswa di kelas kontrol. Adanya perbedaan motivasi antara kelas eksperimen dan kelas kontrol karena di kelas eksperimen penggunaan adobe flash menarik bagi siswa, adobe flash memiliki fitur yang inovatif; c) motivasi belajar siswa di kelas eksperimen berada pada taraf sangat baik, yakni 117 dari nilai ideal 120. Siswa kelas kontrol berada pada taraf baik, sebanyak 92,8 dari skor ideal 120. Temuan ini serupa dengan penelitian Darari (2017) bahwa siswa yang menerima media pembelajaran dengan menggunakan media Adobe Flash memiliki semangat dan motivasi yang tinggi pada saat mengikuti pembelajaran. Motivasi juga dapat meningkatkan kreativitas ketika memecahkan masalah (Mulyaningsih, 2015).

Hal ini selaras dengan pendapat yang dikemukakan oleh Schunk et al., (2012) bahwa motivasi dapat memengaruhi pembelajaran baru serta kinerja dari keterampilan, strategi, dan perilaku yang sudah dipelajari sebelumnya. Motivasi siswa pada saat pembelajaran menulis cerita pendek tampak pada saat mereka mengerjakan tugas dengan bantuan adobe flash karena adobe flash menyebabkan siswa menjadi tertantang untuk menyelesaikan soal-soal yang diberikan guru. Inilah implikasi penggunaan metode discovery learning berbantuan adobe flash terhadap pembelajaran menulis cerita pendek. Adapun kelemahan dari penggunaan metode ini yaitu belum tersentuhnya aspek keterampilan pada saat media adobe flash digunakan karena ketika media adobe flash digunakan bersama metode discovery learning hanya aspek pengetahuanlah yang lebih dominan tereksplor dari kompetensi siswa.

\section{Asosiasi antara KMTCP dan MB di Kelas Eksperimen}

Asosiasi antara KMTCP dengan MB dianalisis menggunakan tabel kontigensi seperti tercantum pada tabel. Tabel 4 dan tabel 5 untuk kelas eksperimen sedangkan tabel 5 dan tabel 6 untuk kelas kontrol. Penelitian ini membuktikan bahwa terdapat asosiasi antara KMTCP dengan MB, berdasarkan penghitungan tabel Symmetric Measures diketahui hubungan antara keduanya dengan nilai $0,468 / 0,816=0,57$ yang berarti hubungannya cukup kuat. Data pada tabel 4 menunjukkan bahwa KMCTP siswa yang rendah berasosiasi dengan MB yang rendah juga, demikian juga siswa yang KMTCP nya sedang berasosiasi dengan MB nya sedang. Hal itu 
berlaku juga pada siswa yang KMTCPnya tinggi berasosiasi dengan siswa yang MBnya tinggi.

Tabel 4.

Asosiasi antara KMTCP dan MB di Kelas Eksperimen

\begin{tabular}{lcccc}
\hline KMCTF & \multicolumn{3}{c}{ Jumlah } \\
\hline & Rendah & Sedang & Tinggi & \\
Rendah & 5 & 3 & 5 & 13 \\
Sedang & 2 & 0 & 4 & 6 \\
Tinggi & 2 & 0 & 2 & 4 \\
\hline Total & 9 & 3 & 11 & 23 \\
\hline
\end{tabular}

Tabel 5.

Hasil Uji Asosiasi antara KMTCF dan MB di Kelas Eksperimen

\begin{tabular}{lllll}
\hline $\begin{array}{l}\text { Kemampuan } \\
\text { Motivasi Belajar }\end{array}$ & dan & $\begin{array}{l}\text { Koefisien } \\
\text { Kontingensi }\end{array}$ & Sig & \multicolumn{2}{c}{ Interpretasi } \\
\hline KMTCP dan MB & .530 & .000 & $\begin{array}{l}\text { terdapat asosiasi } \\
\text { signifikan pada } \\
\text { signifikansi 5\% }\end{array}$ & $\begin{array}{c}\text { yang } \\
\text { taraf }\end{array}$ \\
\hline
\end{tabular}

\section{Asosiasi antara KMTCP dan MB di Kelas Konvensional}

Pembelajaran menulis teks cerita pendek di kelas kontrol menggunakan metode konvensional, hasilnya diperoleh data seperti tampak pada tabel 6 dan tabel 7. Data ini membuktikan bahwa tidak terdapat asosiasi antara KMTCP dengan MB siswa.

Tabel 6.

Asosiasi antara KMTCP dan MB di Kelas Konvensional

\begin{tabular}{lcccc}
\hline KMTCP & \multicolumn{3}{c}{ MB } & \\
\cline { 2 - 4 } & Rendah & Sedang & Tinggi & Jumlah \\
Rendah & 0 & 3 & 2 & 5 \\
Sedang & 4 & 6 & 2 & 12 \\
Tinggi & 4 & 2 & 0 & 6 \\
\hline Total & 8 & 11 & 4 & 23 \\
\hline
\end{tabular}

Tabel 7.

Hasil Uji Asosiasi antara KMTCF dan MB di Kelas Kontrol

\begin{tabular}{llll}
\hline $\begin{array}{l}\text { Kemampuan dan } \\
\text { Motivasi Belajar }\end{array}$ & $\begin{array}{l}\text { Koefisien } \\
\text { Kontingensi }\end{array}$ & Sig & \\
\hline & & \\
\hline KMTCP dan MB & .666 & .000 & $\begin{array}{l}\text { Tidak terdapat asosiasi } \\
\text { antara kemampuan } \\
\text { menulis teks cerita } \\
\end{array}$ \\
& & $\begin{array}{l}\text { pendek dengan motivasi } \\
\text { belajar }\end{array}$ \\
\hline
\end{tabular}




\section{Kesulitan Siswa dalam Menulis Teks Cerita Pendek}

Berdasarkan hasil uji postes terhadap kemampuan menulis teks cerita pendek diperoleh data hasil tes pengetahuan dan tes keterampilan sebagai berikut.

Hasil Postes Pengetahuan

Tabel 8.

Persentase Perolehan Hasil Postes Pengetahuan

\begin{tabular}{|c|c|c|c|}
\hline \multirow{2}{*}{$\begin{array}{l}\text { NO } \\
\text { Soal }\end{array}$} & \multirow[t]{2}{*}{ Indikator } & \multicolumn{2}{|c|}{ Kelas } \\
\hline & & Kontrol (\%) & Eksperimen (\%) \\
\hline 1 & Latar suasana & $91 \%$ & $100 \%$ \\
\hline 2 & Amanat & $96 \%$ & $100 \%$ \\
\hline 3 & $\begin{array}{l}\text { Norma kebajikan dalam } \\
\text { cerpen }\end{array}$ & $83 \%$ & $91 \%$ \\
\hline 4 & Abstrak & $83 \%$ & $87 \%$ \\
\hline 5 & Orientasi & $74 \%$ & $78 \%$ \\
\hline 6 & Bentuk cerpen & $78 \%$ & $78 \%$ \\
\hline 7 & Kaidah cerpen & $74 \%$ & $78 \%$ \\
\hline 8 & Ciri cerpen & $87 \%$ & $96 \%$ \\
\hline 9 & Latar tempat & $100 \%$ & $100 \%$ \\
\hline 10 & Latar budaya pengarang & $70 \%$ & $74 \%$ \\
\hline 11 & Nilai budaya & $87 \%$ & $91 \%$ \\
\hline 12 & Nilai sosial & $43 \%$ & $87 \%$ \\
\hline 13 & Penerapan nilai moral & $65 \%$ & $70 \%$ \\
\hline 14 & Perwatakan tokoh & $78 \%$ & $83 \%$ \\
\hline 15 & Perwatakan tokoh & $83 \%$ & $83 \%$ \\
\hline 16 & Perwatakan tokoh & $83 \%$ & $87 \%$ \\
\hline 17 & $\begin{array}{l}\text { Pengenalan Antagonis } \\
\text { dan protagonis }\end{array}$ & $87 \%$ & $87 \%$ \\
\hline 18 & Orientasi & $70 \%$ & $74 \%$ \\
\hline 19 & Komplikasi & $70 \%$ & $70 \%$ \\
\hline 20 & Evaluasi & $52 \%$ & $56 \%$ \\
\hline
\end{tabular}

Ketentuan siswa mengalami kesulitan didasarkan pada perolehan persentase skor SMI yaitu dengan membandingkan jumlah skor siswa per item soal dengan jumlah skor SMI per item soal dikali 100, dengan kriteria:

a) Jika persentase skor SMI lebih dari $65 \%$ berarti siswa tidak mengalami kesulitan dalam menyelesaikan soal.

b) Jika persentase skor SMI kurang dari $65 \%$ berarti siswa mengalami kesulitan dalam menyelesaikan soal.

Berdasarkan data pada tabel 8 diketahui pada kelas eksperimen siswa mengalami kesulitan pada soal nomor 20, yaitu tentang mengevaluasi isi cerita pendek. Adapun di kelas kontrol siswa mengalami kesulitan pada soal nomor 12 dan soal nomor 20. Soal nomor 12 yaitu tentang nilai sosial yang terdapat dalam cerita pendek, sedangkan soal nomor 20 tentang mengevaluasi cerita pendek. Soal nomor 20 sama-sama termasuk kategori sulit baik di kelas kontrol maupun di kelas 
eksperimen. Para siswa kesulitan dalam menjawabnya. Soal nomor 20 ini merupakan soal kognitif jenjang kelima, yaitu evaluasi. Menurut tingkatan taksonomi Bloom hasil revisi Anderson dan Krathwohl, jenjang kognitif evaluasi ini merupakan jenjang kognitif tingkat tinggi (Dinni, 2018). Indikator berpikir tingkat tinggi mencakup menganalisis, mengevaluasi, dan mencipta (Wikanengsih, 2020). Lain halnya dengan pendapat Sani (2019) bahwa berpikir tingkat tinggi mencakup berpikir kritis, logis, reflektif, metakognitif, dan kreatif. Temuan ini berarti bahwa para siswa, baik di kelas eksperimen maupun di kelas kontrol belum memiliki kemampuan dalam berpikir tingkat tinggi. Hal ini memperkuat hasil penilaian yang dilakukan PISA bahwa kemampuan berpikir tingkat tinggi para siswa Indonesia masih rendah.

Tabel 9.

Persentase Pencapaian Indikator Soal Keterampilan

\begin{tabular}{|c|c|c|c|}
\hline \multirow[b]{2}{*}{ No. } & \multirow[b]{2}{*}{ Aspek yang dinilai } & \multicolumn{2}{|c|}{ Kelas } \\
\hline & & $\begin{array}{c}\text { Kontrol } \\
(\%)\end{array}$ & $\begin{array}{l}\text { Eksperimen } \\
(\%)\end{array}$ \\
\hline 1 & $\begin{array}{l}\text { Unsur-unsur terkandung dalam cerita pendek yang ditulis meliputi } \\
\text { unsur intrinsik, unsur ekstrinsik. }\end{array}$ & $43,47 \%$ & $74 \%$ \\
\hline 2 & Keterpaduan struktur kalimat pada cerita pendek dan keaslian gagasan & $78,3 \%$ & $87 \%$ \\
\hline 3 & $\begin{array}{l}\text { Kesesuaian dan keterpaduan penggunaan bahasa dalam cerita pendek } \\
\text { yang dibuat }\end{array}$ & $87 \%$ & $91 \%$ \\
\hline 4 & Unsur kebahasaan dan struktur cerita pendek secara runtut. & $64 \%$ & $76 \%$ \\
\hline 5 & Nilai-kehidupan dalam cerita pendek & $96 \%$ & $100 \%$ \\
\hline
\end{tabular}

Data tabel 9 menggambarkan bahwa siswa mengalami kesulitan dalam aspek unsur cerita pendek, unsur kebahasaan dan struktur cerita pendek, sedangkan siswa di kelas eksperimen semuanya tidak mengalami kesulitan di setiap aspek karena capaian semua aspek di atas 65\%. Pencapaian hasil uji keterampilan di kelas eksperimen ini membuktikan bahwa metode discovery learning berbantuan adobe flash dapat mengatasi kesulitan siswa pada ranah kognitif sehingga ketika praktik menulis cerita pendek semua siswa di kelas eksperimen tidak mengalami kesulitan meskipun pada soal kognitif jenjang evaluasi siswa kelas eksperimen mengalami kesulitan dalam menjawabnya.

\section{SIMPULAN}

Selain dapat meningkatkan kemampuan menulis dari segi pengetahuan dan keterampilan, penggunaan metode discovery learning juga dapat meningkatkan motivasi belajar siswa. Hal itu karena metode discovery learning berbantuan adobe flash mangandung kegiatan mengamati, merumuskan permasalahan yang dihadapi, dan pemecahan masalah. Ke depan, perlu dilakukan penelitian lanjut dengan menambah variabel lain pada materi lain sehingga dapat memperkaya khazanah pengetahuan bagi kemajuan pendidikan dan pengajaran bahasa Indonesia.

\section{DAFTAR PUSTAKA}

Agustina, K. A., Artawan, G., \& Astika, I. M. (2015). Penggunaan Film Pendek untuk Meningkatkan Kemampuan Menulis Cerpen Kelas IX A SMP Negeri 1 Gerokgak. Jurnal Pendidikan Bahasa Dan Sastra Indonesia Undiksha, 3(1), $1-12$.

Boko, Y. A., \& Saleh, S. (2020). Penggunaan Metode Quantum Learning dalam 
Meningkatkan Kemampuan Menulis Cerpen pada Siswa Kelas VIII SMP Negeri 12 Kota Ternate. JURNAL PENDAS (Pendidikan Sekolah Dasar), 1(2), 39-46.

Chusni, M., \& Edy, S. (2014). Penerapan Model Pembelajaran Discovery Learning Terhadap Hasil Belajar Siswa Kelas X Tav pada Standar Kompetensi Melakukan Instalasi Sound System di SMK Negeri 2 Surabaya. Jurnal Pendidikan Teknik Elektro, 3(2), 1996-1997.

Darari, M. B. (2017). Penggunaan Media Adobe Flash Pada Pembelajaran Kesebangunan dalam Meningkatkan Kemampuan Pemecahan Masalah Matematika Siswa SMP Negeri 7 Medan. Handayani, 7(2 Juni), 33-41.

Dewi, N. P. E. F., Martha, I. N., \& Wendra, I. W. (2016). Kesulitan Belajar Keterampilan Menulis Cerita Pendek Siswa Kelas IX C SMP Negeri 3 Singaraja Tahun Pelajaran 2016/2017. Jurnal Prodi Pendidikan Bahasa dan Sastra Indonesia Undhiksa, 5(3), 1-12.

Dinni, H. N. (2018). HOTS ( High Order Thinking Skills ) dan Kaitannya dengan Kemampuan Literasi Matematika. Prosiding Seminar Nasional Matematika, 1, 170-176.

Hidayati, P. P. (2009). Teori Apresiasi Prosa Fiksi. Bandung: Prisma Press Prodaktama.

Hudhana, W. D., \& Sulaeman, A. (2019). Pengembangan Media Video Scribe dalam Peningkatan Kemampuan Menulis Cerpen Berbasis Karakter Siswa Kelas X SMA se-Kabupaten Tangerang. Pena: Jurnal Pendidikan Bahasa dan Sastra, 9(1), 31-46.

Kurnianingtyas, E. (2015). Penerapan Teknik Copy The Master Untuk Meningkatkan Keterampilan Menulis Cerpen Siswa Kelas VII-B Mts. Darun Najah Petahunan Lumajang. Nosi, 2(8), 30-40.

Kusnida, F., Mulyani, M., \& Su, A. (2015). Keefektifan Penggunaan Media Audio Visual Dan Media Komik Strip dalam Pembelajaran Menulis Cerpen Yang Bermuatan Nilai-Nilai Karakter Berdasarkan Gaya Belajar. Seloka - Jurnal Pendidikan Bahasa Dan Sastra Indonesia, 4(2), 111-117.

Lailiya, R. I. (2015). Pengembangan Media Pembelajaran Berbasis Adobe Flash CS6 pada Materi Jurnal Penyesuaian Perusahaan Dagang kelas X-AK SMK Muhammadiyah 1 Taman. Jurnal Pendidikan Akuntansi (JPAK), 3(1), 1-7.

Lidiana, H., Gunawan, G., \& Taufik, M. (2018). Pengaruh Model Discovery Learning Berbantuan Media PhET Terhadap Hasil Belajar Fisika Peserta Didik Kelas XI SMAN 1 Kediri Tahun Ajaran 2017/2018. Jurnal Pendidikan Fisika dan Teknologi, 4(1), 33-39. https://doi.org/10.29303/jpft.v4i1.519

Listini, L., \& Saraswati, S. (2017). Meningkatkan Kemampuan Menulis Cerpen Melalui Model Pembelajaran Sinektik Siswa Kelas VII SMP Sandika Sukajadi. Jurnal Bindo Sastra, 1(1), 24-27. https://doi.org/10.32502/jbs.v1i1.664

Maulidta, H., \& Sukartiningsih, W. (2018). Pengembangan Media Pembelajaran Interaktif Berbasis Adobe Flash Untuk Pembelajaran Menulis Teks Eksposisi Siswa Kelas III Sekolah Dasar. Jurnal Penelitian Pendidikan Guru Sekolah Dasar, 6(5), 681-692.

Mulyaningsih, I. (2015). Sastra Anak: Pengembangan Kreativitas melalui Puisi dan Pantun. Cirebon: Nurjati Press.

Musyafa, N. F. (2020). Penggunaan Model Picture and Picture dalam Pembelajaran Menulis Cerpen. Alinea: Jurnal Bahasa, Sastra, dan Pengajaran, 9(1), 37-48. 
https://doi.org/10.35194/alinea.v9i1.626

Mutmainna, F., \& Jafar, A. F. (2015). Komparasi Hasil Belajar Fisika melalui

Metode Discovery Learning dan Assignment And Recitation. Jurnal Pendidikan Fisika, 3(1), 46-51.

Muyaroah, S., \& Fajartia, M. (2017). Pengembangan Media Pembelajaran Berbasis Android dengan menggunakan Aplikasi Adobe Flash CS 6 pada Mata Pelajaran Biologi Abstrak. 6(2301), 79-83.

Nasution, R. S., Solin, M., \& Lubis, M. (2020). The Development of Synectic Models in Learning Writing in Short Story in the Class XI of Medan UISU High School. Budapest International Research and Critics in Linguistics and Education (BirLE) Journal, 3(1), 251-259. https://doi.org/10.33258/birle.v3i1.758

Pradita, I. (2020). Peningkatan Kemampuan Menulis Cerita Pendek melalui Penggunaan Media Gambar pada Siswa Kelas IX SMP Swasta Budi Utomo Binjai Tahun Pelajaran 2020/2021. Jurnal Penelitian, Pendidikan Dan Pengajaran: JPPP, 1(3), 245-256.

Rahmaibu, F. H., Ahmadi, F., \& Prasetyaningsih, F. D. (2016). Pengembangan Media Pembelajaran Menggunakan Adobe Flash untuk Meningkatkan Hasil Belajar PKn. Jurnal Kreatif: Jurnal Kependidikan Dasar, 7(1), 1-10.

Sani, R. A. (2019). Pembelajran Berbasis HOTS (Higher Order Thingking Skills). Tangerang: Tira Smart.

Sanjaya, W. (2012). Media Komunikasi Pembelajaran. Jakarta: Kencana Prenada Media Group.

Saputro, A. N. (2017). Pengembangan Buku Ajar Menulis Cerita Pendek yang Berorientasi pada Karakter Cinta Tanah Air. Indonesian Language Education and Literature, 2(2), 192-202.

Sardiman. (2003). Interaksi dan Motivasi Belajar. Jakarta: Raja Grafindo Perkasa.

Sarudi, W. (2018). Penggunaan Media Kartu Gambar Berseri untuk Meningkatkan

Kemampuan Menulis Cerpen Siswa Kelas IX G SMPN 3 Wates Kediri. Hasta Wiyata, 1(1), 52-61. https://doi.org/10.21776/ub.hastawiyata.2018.001.01.06

Schunk, D. H., Pintrich, P. R., \& Meece, J. L. (2012). Motivasi dalam Pendidikan: Teori, Penelitian, dan Aplikasi. Jakarta: PT. Indeks.

Sugiyono, S. (2010). Metode Penelitian Kuantitatif dan Kualitatif dan R\&D. Bandung: Alfabeta.

Thobroni, Muhammad \& Mustofa, A. (2011). Belajar dan Pembelajaran. Yogyakarta: Ar-Ruzz Media.

Uno, H. B. (2014). Model Pembelajaran Menciptakan Proses Belajar Mengajar yang Kreatif dan Efektif. Jakarta: Bumi Aksara.

Wikanengsih. (2020). Evaluasi Pembelajaran Bahasa dan Sastra Indonesia. Manggu. Bandung: Manggu.

Wulandari, T., Fuady, A., \& Sumarwati, S. (2012). Peningkatan Motivasi dan Kemampuan Menulis Puisi Melalui Penerapan Metode Menulis Berantai pada Siswa Sekolah Menengah Atas. BASASTRA Jurnal Penelitian Bahasa, Sastra Indonesia dan Pengajarannya, 1(1), 77-92. 